\title{
COMMUNITY NURSING Towards Primary Health Care
}

\section{REBECCA BERGMAN RN, EdD \\ Professor and Chairperson of Nursing, Tel Aviv University}

\section{DEVELOPMENT OF COMMUNITY HEALTH}

\section{Early civilisations}

Community health practice in various forms has been recorded for over 5000 years (Anderson, 1969). The ancient Egyptians developed a community system for water supply and sewage disposal. The Hebrews focused on the promotion of health through the Mosaic code which regulated personal hygiene, food, sanitation, maternal health, and more. The Greeks (500-100 BC) emphasised values of personal hygiene and exercise. The Romans (100 BC - $500 \mathrm{AD})$, on the other hand, were concerned with the State rather that the individual and set public health measures in relation to building regulations, water supply and community sanitation.

These early societies laid the foundations of public health, which then suffered a severe decline in the dark ages (500-1500 AD). Society of those centuries, steeped in mediaeval mysticism, rejected the body and glorified the spirit. Pandemics of cholera and bubonic plague scourged Europe, accompanied by the breakdown of government and community systems. The Renaissance (1450-1600) spirit of inquiry brought new hope for health with measures of sanitation and isolation based on a general understanding of the nature of communicable disease.

\section{The modern era}

The modern era. from the mid ' 1800 s was blessed with public health trailblazers such as Chadwick in Britain and Shattuck in the United States. Their work, in a period when it was believed that disease was caused by noxious air or vapours, outlined principles which

\section{OPSOMMING}

Die primêre gesondheidsorg-benadering is eintlik nie 'n totaal nuwe begrip nie - dit het ontstaan uit jare se kennis en ervaring van gemeenskapsorg. Dit is egter noodsaaklik dat die begrippe nie net op teoretiese vlak bly nie, maar in die praktyk toegepas word.

Verpleegkundiges was onder die eerstes om die uitdaging van primêre gesondheidsorg te aanvaar maar tog is daar vrae en konflikte wat opgelos moet word.

Verpleegstersverenigings kan ook ' $n$ belangrike rol vertolk in die bereiking van die doelwitte van primêre gesondheidsorg. By 'n IRV/WGO-vergadering is sewe aanbevelings as raamwerk vir verpleegstersverenigings se betrokkenheid opgestel. Daar is reeds opwindende voorbeelde van projekte wat deur verpleegkundiges onderneem is.

are still the foundations of community health: the establishment of boards of health, vital statistics. sanitation programmes, care of groups at-risk, public and professional education

Discoveries by scientists such as Pasteur and Koch developed methods of disease control. Immunisation programmes were the core of public health.

The role of community nursing began to develop at that time, such as the work of Rathbone and Nightingale in England; and Lillian Wald and Mary-Brewster in New York. Nursing grew like Topsy - involuntary and official agencies; curative and preventive programmes; specialised fields such as tuberculosis, maternal health. school health, and industry.

Nurses did much to develop and implement health promotion and health education. They were among the first of the professions to see the value of total family care rather than isolated programmes for family members. Maternal and child health centres were re-named family health centers. Emphasis on the community as the client was a further extension of family-focused care.

In many countries, nurses were the founders of public health programmes. In Israel, for instance, community health services were organised by nurses. Physicians and other health professionals were invited to serve as specialists for specific tasks. In North America and some other lands, public health nursing was in its hey-day - with higher educational preparation, higher status, more autonomy and rewards than in any other branch of nursing.

It is dared to suggest, that by and large in the 1960s and 70s, public health nursing - in fact all public health practice - rested on its laurels and made little progress, while curative care expanded and adapted to scientific and social changes.

\section{The new approach}

The rise of social-political movements was reflected in the health policy of many countries. The public, politicians, and health care providers became aware of social deprivation and social pathology as health problems. They recognised that help must be provided to the vast underserved populations in rural areas and inner cities. Community health had to reach out in many ways - to provide service in remote geographic areas, to reach deprived population groups, to seek co-ordination with other sectors such as housing, education, and agriculture. Above all - a new approach to the community was essential, to respect their potential as partners in health care. 
Governments, the World Health Organization (WHO), and the health professions realised that to a degree they had not achieved the desired health goals by using a paternalistic approach to community health. They also realised that no society, not even the richest, could carry the financial burdens of health care provided only by employed staff in institutional settings. WHO took the leadership role. The catch phrase for the new approach was primary health care - health for all by the year 2000

\section{Alma Ata}

It became the central theme in international health and social forums and was formalised in 1978 at Alma Ata. The major points of the Alma Ata declaration (WHO, 1978) are:

- people have the right and duty to participate in the planning and implementation of their health care

- governments have the responsibility for the health of their people

- primary health care should:

- be at a cost the community and country can afford,

- be an integral part of the health system and the social and economic development of the community,

- involve all related sectors of national and community development,

- bring health care as close as possible to where people live and work.

- provide promotive, preventive, curative and rehabilitative services,

- utilise a broad varity of health workers including physicians, nurses, midwives, auxiliaries, community workers and traditional healers.

\section{Primary Health Care}

What was new about primary health care? The content areas had been long established in publications called basic health care programmes. Integration of curative and preventive services was recognised as a desirable plan and established in many settings. Co-operation with other sectors and community involvement in planning and implementing care had been proposed half a century earlier. At the turn of the century Lillian Wald wrote nurses have an organic relationship with the neighbourhood in no sense is nursing an isolated undertaking - nurses should work together with all agencies and groups working for social betterment (Tinkham and Voorhies, 1972).

What is shown above is that the primary health care approach is not completely new. It is the outgrowth of community care knowledge and experience over the years. The trouble is that the ideas had largely remained at the theoretical level and were not sufficiently accepted in practice. We needed to be rudely awakened from our lethargy and our satisfaction with the role of a paternalistic dispenser of wisdom. We had to really look and to see the unmet health and social needs. We had to revamp our perceptions of people in the community. We needed to recognise, respect, and support their abilities to make decisions and to carry all or partial responsibility for their individual and community health needs.

Nursing was among the first to accept the changes proposed in primary health care. We, more than any other group, are closely involved with the community in all life stages, in all settings, and all health conditions. Nursing is par excellence a caring and a curing profession. Teaching and organising are major tools in nursing. Nursing education draws upon nursing, social and medical sciences - the essentials of primary health care.

Many nurses and nursing groups picked up the challenge. The community nurse practitioner movement with both generalised (family) and specialised (such as paediatric, geriatric) nurses emerged in the United States and later in other countries such as Jamaica and South Africa. In some countries, nursing leaders in the nurses' association, government, and voluntary agencies took the initiative to promote primary health care.
QUESTIONS AND CONFLICTS FACED BY NURSES

However, nursing as a profession faced many questions and conflicts related to primary health care. Some of the major ones are discussed.

\section{Applicable to developed countries?}

Primary health care as envisioned at Alma Ata, is fashioned to meet needs in developing countries with limited services and a scarcity of health professionals. Many people think that it is not appropriate for countries with extensive health services and an adequate supply of doctors and nurses.

In such situations, one must ask additional questions. Are the services available to all citizens? We know that there are unserved populations - the poor, the aged, residents of rural areas and inner cities. Are services given by the care giver who is most effective, and at the lowest cost to society and the patient? Many research projects have shown that nurses provide equally good or better first level health care to families at a lower cost than physicians in both developed and developing countries.

Analysis of these issues leads to the conclusion that primary health care nursing is needed in all countries, but that the major role of the nurse in a more affluent society would be that of a direct primary care giver; while in countries with limited resources, the professional nurse would function mostly as a teacher and supervisor of auxiliary and voluntary workers (Bergman, 1980).

\section{Training of auxiliaries}

The Declaration of Alma Ata recommends extensive use of auxiliary personnel, traditional healers, and volunteers. This raises the question of who should teach and supervise such workers. Nurses in general believe that these are professional nursing functions. However, some physicians, administrators, and experienced auxiliaries propose that a career ladder prepare selected auxiliaries for the above functions. This stand was put forward at a number of international meetings and was rejected by nurses. It is submitted that nursing must stand firm on this question. 


\section{Proliferation of nursing categories}

Nurses are concerned about proliferation of levels of nursing personnel. Some feel that auxiliary groups may take over professional nursing activities and thus lower the standard of care. They are also fearful that administrators may prefer to hire low-cost auxiliaries, thus causing unemployment of nurses.

On the other hand, rejection of the use of auxiliary workers could seriously impede provision of needed services. It has been stated by knowledgeable international nurses that if international agencies and governments so wished. they could prepare nurses at an appropriate level in sufficient quantity to meet most primary health care needs within a few years. In this way, quantity and quality needs could be met. Nursing, nationally and internationally, must urge that resources be made available for preparation of more nurses.

\section{Diagnosis and treatment}

Another issue is whether nurses should make first-level medical diagnoses and determine treatment. We must keep in mind that much illness can be prevented by health education, immunisation, proper nutrition, and sanitation. Further. for years, nurses have diagnosed and proposed treatment for common conditions.

The WHO Expert Committee on Community Health Nursing (1974) described the future role of the community nurse to include ... examining the sick and disabled, determining the source of the problems presented, and treating acute conditions as well as major prevalent diseases in the community.

Many physicians categorically refute such a role for nurses. Some nurses are also perturbed by this extended role. They say we will give up first-class nursing to do secondclass medicine. On the other hand. others believe we will replace second-class primary medical care (not comprehensive in scope, pathology focused) with expanded, revitalised first-class community nursing.

\section{Community as partners in care}

The most important principle is, in the author's opinion, sincere acceptance of the client/community as partners in the health care endeavour. Few nurses would negate the idea, although some will add that most patients are not able to share in decision-making and to undertake self-care. It is believed that almost every person, to some degree, can be a partner in his care.

A recent Master thesis (Kapoor. 1983) examined patient involvement in a variety of primary health care settings in New Zealand. The author reported that three-quarters of the staff and patients stated that the clients should be part of the team - yet only $20 \%$ felt this was so in practice.

A basic change is essential in our attitude to involvement of patients in their care. It is our responsibility to promote this principle in both education and practice.

\section{Integration of services}

Primary health care calls for integrated and continuing services Again, while most nurses and organisations accept the principle, many are reluctant to relinquish their established separated/specialist services. Cadres of nurses have been trained as specialists, and they no longer feel secure in other areas of care. This reluctance to relinquish well-functioning services is understandable.

How to meet these conflicting needs is one of the many problems to be solved. It will require gradual re-organisation of established services, with intensive inservice education for practitioners. New services and basic education need to be in line with the principles of integration and continuity.

\section{Nurses in policy-making}

Primary health care requires interprofessional and intersectional partnership at all levels, including policy-making. Some governments and agencies do not appoint nurses to top-level positions. Often, nurses in top positions do not have the status and/or qualifications to function as equal colleagues in policymaking.
The nurses' association is a force for change in many countries; in others, the association has limited influence because of legal restrictions or other reasons

Active nursing participation in policy-making for primary health care is essential. In fact, nursing should be an initiating force. Preparation for a policy-making/political role, including the gathering of data and presentation of recommendations, is one of the areas which requires the full attention of the profession.

\section{Role of nurses' associations}

We can all be proud that the International Council of Nurses was one of the first groups to recognise and promote the nurse's role in primary health care. At the ICN congress in Japan in 1977, Olive Anstey, the then newly elected ICN president, stated: My goal is to promote more resources, both financial and human, to the further development of PHC (Anstey; 1977). In the past seven years, ICN has worked closely with WHO. UNICEF, and the national nurses' associations to make this goal a reality.

At an ICN/WHO meeting in Kenya in 1979, nurses from 61 countries formulated seven major recommendations as the framework for national nurses' associations to work for primary health care (News, 1980):

- National nurses' associations should be aware of national health policies, national interpretations of primary health care, and the situation of nursing in the country in order to be able to participate in the planning and implementation of primary health care and to provide information to nurses and to others.

- Because of their responsibility for shaping the direction of nursing, national nurses' associations should decide on the major areas in nursing which need to be reviewed and/or changed in line with primary health care policies. There is a need to make changes in nursing education programmes, to redefine and restructure the roles and functions of health workers and to conduct research to determine problems affecting nursing. 
- Because effective planning and co-ordination of activities between the health and other sectors is essential in order to bring about significant improvements in the health of all people, national nurses' associations should develop and/or strengthen effective relationships with other groups.

- In order to translate policies for primary health care into action, national nurses' associations should set up their own plans of action as these relate to nursing, taking into account the needs and available resources within the country.

- Because development of primary health care will depend on the attitudes and capacities of all health workers, national nurses' associations should give high priority to the promotion of the team spirit among nurses and with other disciplines.

- National nurses' associations should ensure that nursing practice, incorporating primary health care goals, is supported by appropriate legislation.

- ICN should facilitate the exchange of information and expertise among national nurses' associations in order that they may learn from each other in matters of nursing related to health development.

\section{Examples of nurses' activities}

There are many exciting examples of the activities of individuals and groups in primary health care.

Mrs. Flora Makatoko, a public health nurse supervisor in Lesotho worked with tribal chiefs in the mountain villages to explain primary health care and then trained the village health workers nominated by the communities. There has been considerable improvement in the health status of the population with a decline in kwashiorkor, dysentery, whooping cough, and tuberculosis (News, 1979).

In the Philippines, the nurses' association set up a demonstration clinic in Parang, a shanty town outside Manila. The half-time association nurse, working with community volunteers whom she trained, succeeded in cleaning the contaminated water sources, building sealed toilets, and starting home gardens and small animal husbandry. They provided basic curative and preventive care in a modest clinic and in the homes, as well as home deliveries for normal pregnancies. This model has been used by other branches of the association, and many such clinics have since been established (WHO, 1979).

In Israel, nurses employed in Kupat Holim (health insurance of the Federation of Labour) developed a home care programme for bedridden chronically ill as an extension of the services of the primary community clinics. To date, 15000 patients are receiving home care. As a result, severe chronically ill patients can remain at home with their families instead of being institutionalised. The nurses also follow up ambulatory patients with chronic illness. They provide preventive and maintenance care to 100000 persons with diabetes or hypertension. Guidelines have been developed for nursing care, standing medical orders, and educational programmes for staff and patients.

In the area of education, a WHO project is examining present practices, needs, and resources for primary health care education in nine countries. ICN is also working with the League of Red Cross Societies on a programme for nurses to train locally selected community health care workers and volunteers.

Primary health care projects need to be evaluated. The evidence of achievements in improving health by nursing intervention in primary health care is myriad. The following are good examples. Research on a day-centre for diabetes project in San Francisco shows that a nurseled intensive programme in selfcare for diabetes patients resulted in:

- $77 \%$ of the patients in good control compared with $13 \%$ before the programme

- marked reduction in the need for emergency care (from 18 to one patient)

- initiation of insulin and the correction of control regime was possible without hospitalisation (Uris and Kearns, 1983).

The introduction of rural midwives in Georgia reduced infant mortality to $17 / 1000$ in four years while it remained at about 23,5 in comparative countries (Aiken, 1982).

\section{CONCLUSION}

If we take the long view of professional development in community nursing, we see from our discussion that the beginnings are found in experience gained by practice which was undertaken to meet urgent health needs. On this base, educational programmes were developed to prepare practitioners who could give more effective nursing care. The need to evaluate the process and outcomes of nursing practice and education led to research. This professional growth has prepared us to take an active role in national health policy-making in partnership with other groups and professions. This four tier (experience, education, research, policy) enhanced professional ability and is continually fed back into practice, education, research, and policy for improved health for all.

Primary health care is a challenge, an opportunity, a privilege, and an obligation for nurses as individuals and for nursing as a profession.

It is a challenge for us to take stock of ourselves as nurses and of the health care in our countries, to be objective - to be open-minded - to be resourceful and creative.

It is an opportunity to be part of an interdisciplinary, intersectional, world-wide movement, and to take our place as colleagues with others in policy-making and programme development for health.

It is a privilege to be able to participate in this goal-directed, exciting, innovative revolution in health care.

It is an obligation that we undertook when we became nurses - to make every effort to improve the health of our peoples.

We must each accept and act upon the challenge, opportunity, privilege, and obligation at two levels:

each of us, individually, in our own way at the appropriate time and place;

and, all of us together, as an aggregate force at the national, regional, and international forums.

Continued on p. 56 